\title{
CLINICAL ASSESSMENT AND MANAGEMENT OF EQUINE WOUNDS
}

\author{
El-Sayad, G. A.; Zaghloul, A.E* and Karrouf, G.l.* \\ Dept. of Surgery, Fac. Vet. Med., Kafr EL-Sheikh, Tanta University. \\ ${ }^{*}$ Dept. of Surgery, Anesthesiology \& Radiology, Fac. Vet. Med., Mansoura University.
}

\begin{abstract}
The present study was carried on 355 drafting equine (135 horses, 210 donkeys and 10 mules)suffered from different varieties of skin wounds. These animals were subjected to full clinical study including history, physical and clinical inspection in addition to parasitological and hist-opathological examinations for the suspected non-traumatic lesions. The incidence, according to, the locations of wounds were in the head regions (28.2\%), neck (5.6\%), back (2.8\%), shoulders (5.6\%), chest (4.2\%), gluteal region (2.8\%), and abdomen (5.6\%), fore limbs (19.7\%) and hind limbs (25.4\%). Wounds were treated either by surgical debri-dement, high-pressure lavage, suturing, infusion, lancing, excisions, electro-surgery and/or bandaging. Modified shaped wound defects were closed completely or partially by the aid of centripetal closure, undermining, local skin flap and relaxing incisions.
\end{abstract}

Exuberant granulation tissue was seen as a common complication of wounds of the lower limbs in donkeys and horses. Mal-interference, chemical irritants, motion and infection promote its development. Primary closure was suited to fresh wound that minimally traumatized while in contaminated wounds delayed primary closure was adopted within 4-5 days of injury before the formation of granulation tissue.

\section{INTRODUCTION}

The wounds are the most common surgical affections in equine and they are often treated hesitantly because of misunderstanding or unfamiliarity. Therefore, the treatment is often ineffective and may end the career 
of any equine animal so most clinicians should be familiar with the proper treatment and healing of equine wounds.

The inherent nature of horses predisposes them to traumatic injuries, often complicated by severe local trauma, tissues losses and infections. Lacerations were the most common wounds and often occur at predictable locations. The sites of the wound are of great importance for prognosis and efficient surgical management (Warden, 1987).

The site, severity,duration of the wound,concurrent injury to deeper structure,desired cosmetic results and the intended use of the horse affect the method of treatment. Contaminated wounds of the head can be closed without untoward sequelae, conversely open wound on the limb resulting in less favorable final appearance (Hunt, 1981). Moreover subsequent infections as well as time before treatment, available facilities and temperament of the horse, intended use and the size and location of the wound were determinants of the course of treatment (Romatowski, 1989 and French, 1994).

The density of the regional vasculature and local mobility play a great role in resistance to infection and rate of wound healing. Moreover,the rate of wound contraction differs from an area to another (Walton and Neal, 1972). The separation of skin from its subcutaneous attachment in such way that the dermal blood supply was maintained this allow skin stretching to cover a wound too large to close with tension suture (Peyton, 1981 and Bailey, 1992).

AIM: The equine practitioners often facing the decision to attempt to save a seriously wounded horse, or to perform euthanasia. The question becomes more relevant with animals of minimal economic values like donkeys. The information needed to construct a decision is the probability of healing in addition to the value and cost to reach such healing. The probabilities are derived from the literatures or from clinical experience. Therefore, the aim of this study was to focus light on the different types of equine 
wounds under local relations incidence, etiology of each wound,locations, decisions for appropriate line of treatment and, probabilities of healing in order to return to normal function and the economic options.

\section{MATERIALS AND METHODS}

The present study was carried out on 355 drafting animals: 135 horses, 210 donkeys and 10 mules suffering from different varieties of wounds. They were admitted to the veterinary teaching hospitals at Tanta and Mansoura Universities from different neighbouring localities in addition to field trips.

Animals were subjected to keen clinical studies including complete history,clinical examination and assessment of the wound were performed and recorded in a special sheet based on sites of the wounds, associated inflammatory reactions, shape and nature of the wound,presence or absence of granulation tissues, tissues losses and infection, and involvement of body cavities, or synovial structures.Biopsy and blood samples were taken from the suspected non-traumatic lesions for histopatholgical and parasitological examinations.

The obtained data were collected and tabulated according to the aforementioned wound peculiarities. Wound management was based mainly on the types, available facilities and temperament of the animal. Animals were operated under tranquilization(combelen)and/or deep narcosis using chloral hydrate $(5-6 \mathrm{gm} / 50 \mathrm{~kg}$. b.w.) while physical restraint was enough in most of cases for dressing of minor wounds.

Recent full thickness wound (during 6 hours of injury ) were protected by saline moistened gauze dressing. The surrounding skin was prepared for aseptic surgery, the raged edges were straightened while the necrosed flap tips were excised.Constant pressurized lavage by normal saline was performed during the debridment.In case of minor soft tissue damage with the possibility of primary intention, a rubber drains were installed and 
the wounds were sutured.In contaminated wounds, delayed primary closure was adopted within 4-5 days of injury before the formation of granulation tissues(Fig.1).Unhealthy granulating and neoplastic wounds were excised and sutured when possible (Fig. 2).

Different reconstructive techniques as centripetal closure were performed for closure of most common wound defects by shifting of the surrounding tissues toward the centre of wound defect.The resulted triangular wound defect was closed into Y-shaped suture line(Fig. 3). Large wound defects resulted after surgical excision of unhealthy hypergranulation,fibroblastic sarcoid present in the ventral midline or after removal of fibrous presternal bursitis were closed after undermining and/or multiple relaxing mesh incisions approximately $1 \mathrm{~cm}$ long placed from skin edges and $1 \mathrm{~cm}$ apart (Fig. 4).

Opened fistulous withers were subjected to minor surgical interference in form of lancing and drainage (Fig. 5). In cases of back sores, the cause was removed and the sores were treated by surgical debridement of their surfaces and daily dressed with povidone iodine and zinc oxide ointment while sores complicated by hyprergranulation were surgically excised and daily dressed.

The burnt wounds were washed with normal saline and removal of necrotic tissues, foreign materials and debris were peformed. Areas of burns of first and second degree were topically treated with antibiotic preperations and bandaged in applicable places. In cases of third degree burns, eschars were removed daily until formation of healthy granulation tissues. Topical therapy were used with antibiotic ointm-ents and creams.

The hyprergranulation tissues as a complication to chemical application in the lower limbs were excised to skin surface and bandaged. Critical wounds as wounds involving tendons, synovial sheathes, perforating 
abdominal wounds and biting wounds were treated on the basic principles for each. While treatment of ulcerating ocular granulomas were performed by curetting the unhealthy granulation or its surgical excision followed by systemic Ivermectin.

\section{RESULTS}

The present study revealed that out of 355 drafting animals, 135 horses with a percentage of (38\%), 210 donkeys (59.2\%) and 10mules (2.8\%) were suffered from traumatic and non traumatic wounds. The high percentage of wounds were located at the head region with a percentage of $28.2 \%$ (12.4\% in horses and $14.1 \%$ in donkeys) while the least percentage of wounds were located at back and gluteal region with a percentage of $2.8 \%$ ( $0.7 \%$ in horses and $2.1 \%$ in donkeys). The distribution of wounds in body regions were tabulated in table (1).

Regarding the distribution of wounds in the head region,old wounds constitute the higher percentage $61 \%$ while recent wounds were $39 \%$. The nature and sites of wounds were tabulated in table (2) and (Fig. 6 and 7).

Wounds caused by sharp objects with improper managements were the most common types recorded in this work. [They represented (16\%) among other type of traumatic wounds(Table 3). The history of these cases revealed that the inflicting objects were barbed wires and hooks. The hind limbs, eyelids, cheek and ears were the least common sites of injuries. These wounds ranged from small incised to wide lacerated with excessive soft tissue damage. In addition to 5 penetrating abdominal wounds were noticed (Fig. 8). The incised wounds were healed by first intention while the lacerated one healed partially by the first intention.Two cases with penetrating abdominal wounds with injured and prolapsed intestine were euthanised. 
Wound with dehiscence were recorded in 39 cases as 17 in horses with percentage of $4.8 \%$ and 18 in donkeys $(5.1 \%)$ and 4 cases in mules (1.1\%). Parasitic infestation (habronema, as revealed from the parasitological examinations) were recorded in 35 cases with percentage of $9.9 \%$ as 32 cases in donkeys and 3 cases in mules(Fig.9).The different causes and percentage of equine wounds were recorded on table (3).

Ten donkeys were affected with bite wounds. The neck and head were the most common regions for bites. The bite injures ranged from insignificant simple multiple punctures to bruises,laceration and avulsion. Most of cases showed persistent wound discharge (Fig. 10).

Skin excoriations due to saddle injuries were observed on the back and collar areas among draft donkeys. Sore Back were noticed on the back of donkeys, the lesions were circular and ulcerated areas without tendency to heal with the presence of unhealthy granulation and necrosis in its centre (Fig. 11). Surgical debridement and/or excision and daily dressing results in recovery within about 45 days.

Burns due to thermal injury and chemical irritants were recorded in 30 cases ( 5 thermal and 25 chemical burns). The animals were trapped in housing fires. The burns were ranged from second to third degree covering about $30-70 \%$ of the body surfaces (Fig. 12\&13). The hypergranulating wounds were subjected to surgical excision with complete healing within 2 months.

Out of twenty abdominal wounds, six old granulating wounds appeared as nodules or large exuberant granulations (fibroblastic sarcoid, as revealed from the histopathological examinations)ulcerated and infected at the ventral abdominal wall, and have no tendency to heal (Figs.14). Seven recent (incised, lacerated and avulsed)wounds at the ventrolateral abdominal wall,4 old septic wounds after suture dehiscence on the ventral abdominal wall and 3 perforating wounds with intestinal prolapse were recorded. 
Subcutaneous haematoma were noticed in ten donkeys and one horse. Recent haematoma was large wide voluminous,fluctuating swelling at the gluteal region. Old haematoma appeared as either organized pseudocrepitating swellings or old ulcerating with skin excoriations with abnormal discharge and infected scabs. Healing was obtained within 3-4weeks after lancing and drainage.

Exuberant granulation tissues were diagnosed in the lower parts of rear limb at the level of the fetlock joint, distal ends of the metatarsus to the fetlock joint (Figs. 15) and just caudal to the axillary region. The wide wound defect, produced after excision, was closed after undermining and multiple relaxing incisions.

Wounds of the fore limbs were encountered in 70 cases (19.7\%). 50 cases were old ulcerated septic wounds (24 at the fetlock joint region, 10 at radius and ulna, 2 at the level of carpal joint, 12 at the level of metacarpal region and 2 cases at the level of pastern joint). While the other 20 cases were recent accidental wounds at the medial aspect of radius and ulna, and at the frontal aspect of metacarpal region.

Forty old granulating wounds at the metatarsal region in addition to 5 ulcerating and 24 old septic wounds were observed at the level of the flexor aspect of the hock, fetlock and pastern joints. Two recent open hocks, one recent and 2 old open stifle joints, 12 cases of abrasions and 4 cases of recent accidental wounds at the caudal aspect of the thigh region were recorded.

Wound dehiscence were recorded in 39 animals after initial treatment. Extremities were the most commonly involved regions especially in wounds near to the joints or after removal of sarcoid or exuberant granulation tissue. Two cases were recorded after excision of fibrous olecranon bursitis.

Table (1): Presenting the Distribution of Wounds in Different Body Regions in Equine.

\begin{tabular}{|c|c|c|c|c|c|c|c|c|}
\hline \multirow{2}{*}{$\begin{array}{l}\text { Anatomic } \\
\text { Locations }\end{array}$} & \multicolumn{2}{|c|}{ Total } & \multicolumn{2}{|c|}{ Horses } & \multicolumn{2}{|c|}{ Donkeys } & \multicolumn{2}{|c|}{ Mules } \\
\hline & No & $\%$ & No & $\%$ & No & $\%$ & No & $\%$ \\
\hline
\end{tabular}

Kafr El-Sheikh Vet. Med. J. Vol. 2 No. 2 (2004) 


\begin{tabular}{||l||c|c||c|c||c|c|c|c||}
\hline \hline Head & 100 & 28.2 & 44 & 12.4 & 50 & 14.1 & 6 & 1.7 \\
Neck & 20 & 5.6 & 9 & 2.5 & 11 & 3.1 & -- & -- \\
Back & 10 & 2.8 & 2 & 0.7 & 7 & 2.1 & 1 & 0.3 \\
Shoulder & 20 & 5.6 & 7 & 2 & 11 & 3.1 & 2 & 0.5 \\
Gluteal & 10 & 2.8 & 4 & 1.1 & 6 & 1.7 & -- & - \\
Chest & 15 & 4.2 & 5 & 1.4 & 10 & 2.8 & -- & - \\
Abdomen & 20 & 5.6 & 9 & 2.5 & 11 & 3.1 & -- & - \\
Fore limbs & 70 & 19.7 & 25 & 7 & 44 & 12.4 & 1 & 0.3 \\
Hind limbs & 90 & 25.4 & 30 & 9 & 60 & 16.9 & -- & -- \\
\hline \hline Total & $\mathbf{3 5 5}$ & $\mathbf{1 0 0}$ & $\mathbf{1 3 5}$ & $\mathbf{3 8}$ & $\mathbf{2 1 0}$ & $\mathbf{5 9 . 2}$ & $\mathbf{1 0}$ & $\mathbf{2 . 8}$ \\
\hline
\end{tabular}

Table (2): Showing forms and distribution of wounds in the head regions.

\begin{tabular}{|c|c|c|c|c|c|c|c|c|}
\hline \multirow{2}{*}{ Wound Forms } & \multirow{2}{*}{ State } & \multirow{2}{*}{ locations } & \multicolumn{2}{|c|}{ Horses } & \multicolumn{2}{|c|}{ Donkeys } & \multicolumn{2}{|c|}{ Mules } \\
\hline & & & No & $\%$ & No & $\%$ & No & $\%$ \\
\hline Ulcers & Old & Distal to the eye & $\begin{array}{l}- \\
--\end{array}$ & $\begin{array}{l}- \\
--\end{array}$ & 29 & 58 & 3 & 50 \\
\hline Incised\&lacerated & Recent & Forehead & 11 & 25 & 2 & 4 & -- & -- \\
\hline Incised \& contused & Recent & Eyelids & 8 & 18 & 2 & 4 & -- & -- \\
\hline Amputation,biting & Recent & Ears & -- & -- & 7 & 14 & 1 & 16 \\
\hline Contusion \& ulcer & Old & Supra-orbital & 8 & 18 & 3 & 6 & -- & -- \\
\hline Incised \& avulsed & Recent & Upper lips & 3 & 6.8 & 1 & 2 & -- & -- \\
\hline Incised \& circular & Recent & Lower lips & 3 & 6.8 & 1 & 2 & -- & -- \\
\hline Lacerations & Old & Mouth commissure & 5 & 12.1 & -- & -- & 2 & 34 \\
\hline Avulsed & Recent & Cheek & -- & -- & 2 & 4 & -- & -- \\
\hline Granulating & Old & Nose & 2 & 4.3 & -- & -- & -- & -- \\
\hline Incised\&lacerated & Recent & Nose & 4 & 9 & -- & -- & -- & -- \\
\hline $\begin{array}{l}\text { Neoplastic } \\
\text { (FibroblasticSarcoids) }\end{array}$ & $\begin{array}{l}\text { Old } \\
\text { Ulcerated }\end{array}$ & $\begin{array}{l}\text { Distal to medial } \\
\text { canthus of the eye }\end{array}$ & -- & -- & 3 & 6 & -- & -- \\
\hline Total & & & 44 & 100 & 50 & 100 & $\overline{66}$ & $\overline{100}$ \\
\hline
\end{tabular}

Table (3): Causes of the Different Wounds in Equines.

\begin{tabular}{||l|c|c||c|c||c|c||c|c||}
\hline \multirow{2}{*}{ Causes } & \multicolumn{2}{c|}{ Total } & \multicolumn{2}{c|}{ Horses } & \multicolumn{2}{c|}{ Donkeys } & \multicolumn{2}{c||}{ Mules } \\
\cline { 2 - 9 } \cline { 5 - 9 } & $\mathbf{3 5 5}$ & $\mathbf{\%}$ & $\mathbf{1 3 5}$ & $\mathbf{\%}$ & $\mathbf{2 1 0}$ & $\mathbf{\%}$ & $\mathbf{1 0}$ & $\mathbf{\%}$ \\
\hline \hline Falling and slipping & 47 & 13.2 & 12 & 3.4 & 35 & 9.8 & -- & -- \\
Crushes & 31 & 8.7 & 15 & 4.2 & 16 & 4.5 & -- & -- \\
Improper bandages & 13 & 3.7 & 8 & 2.3 & 5 & 1.4 & -- & -- \\
\hline
\end{tabular}

$\overline{\overline{\text { Kafr El-Sheikh Vet. Med. J. Vol. } 2 \text { No. } 2(2004)}}$ 


\begin{tabular}{|l||c|c||c|c||c|c||c|c||}
\hline \hline Wound dehiscence & 39 & 11 & 17 & 4.8 & 18 & 5.1 & 4 & 1.1 \\
Blows & 3 & 0.8 & 1 & 0.3 & 2 & 0.6 & -- & -- \\
Bites & 10 & 2.8 & -- & -- & 10 & 2.8 & -- & -- \\
Sharp objects & 57 & 16 & 2.5 & 7 & 32 & 9 & -- & -- \\
Improper management & 45 & 12.7 & 25 & 7 & 20 & 5.6 & -- & -- \\
Trailering injury & 22 & 6.2 & 18 & 5.1 & 4 & 1.1 & -- & - \\
Collision with stable objects & 28 & 7.9 & 4 & 1.1 & 23 & 6.5 & 1 & 0.3 \\
Chemical burns & 12 & 3.4 & 5 & 1.4 & 6 & 1.7 & 1 & 0.3 \\
Thermal burns & 6 & 1.7 & 1 & 0.3 & 4 & 1.1 & 1 & 0.3 \\
Parasitic infestation & 35 & 9.9 & -- & -- & 32 & 9 & 3 & 0.8 \\
Neoplastic wounds (fibroblastic sarcoid) & 7 & 2 & 4 & 1.1 & 3 & 0.8 & -- & -- \\
\hline
\end{tabular}

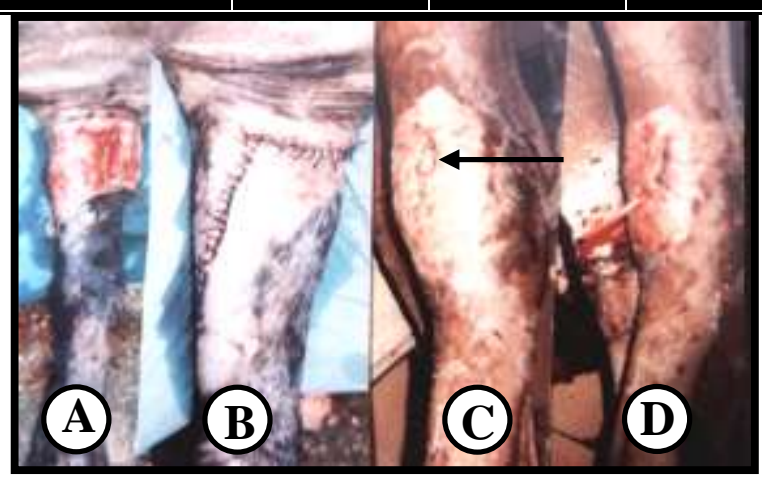

Fig. (1): Recent lacerated wound at the medial aspect of the antibrachium (A) and after primary reconstruction (B).

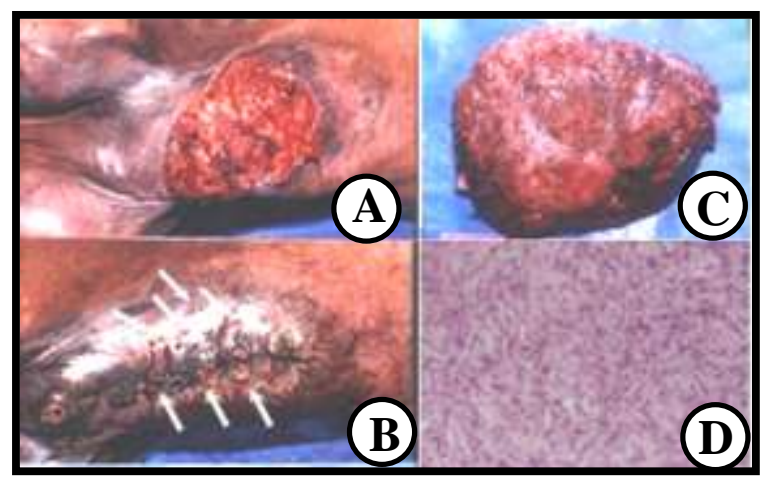

Fig. (2): Exuberant granulation tissues caudal to the axillary region(A);After the secondary closure by the aid of undermining and multiple relaxing incisions (B); The excised granulation mass (C) and The microscopic picture of hypergranulation tissue which characterized by numerous fibroblasts (D) (H\&E.x150). 


\section{(A)}

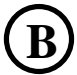

Fig. (3): Triangular wound defect at the level of the shoulder joint (A) closed into Y shaped suture line (B).

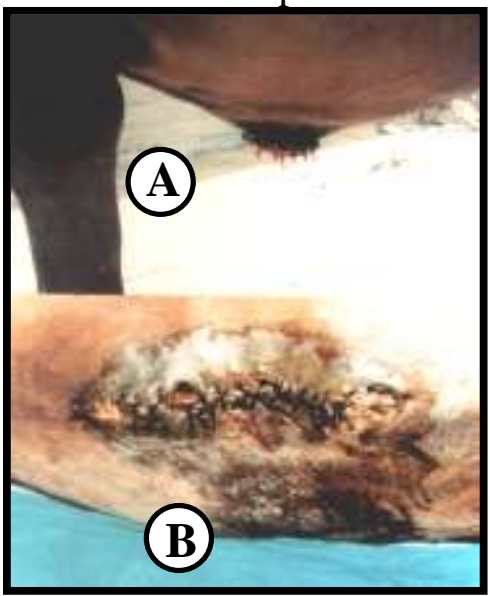

Fig. (4):(A)Fibroblastic sarcoid located at the midventral abdominal wall.

(B) The operated area after surgical excision and secondary closure by the aid of undermining and multiple relaxing incisions.

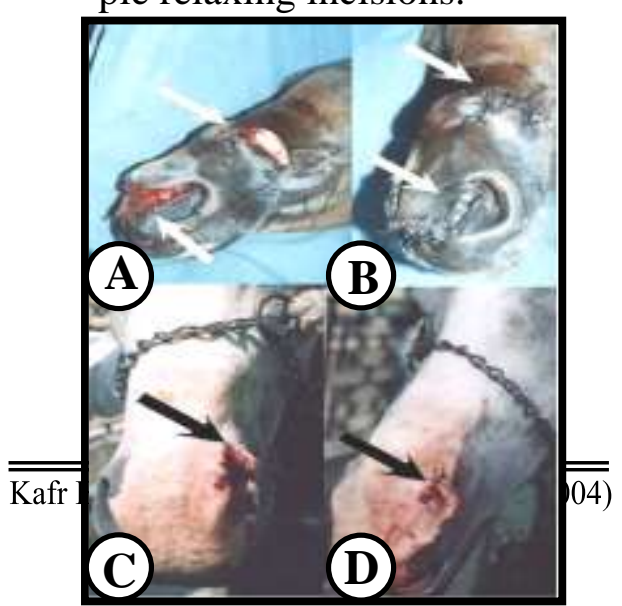

Fig.(6):(A) Recent accidental lacerated wound proximal to the muzzle extending to the medial wall of the

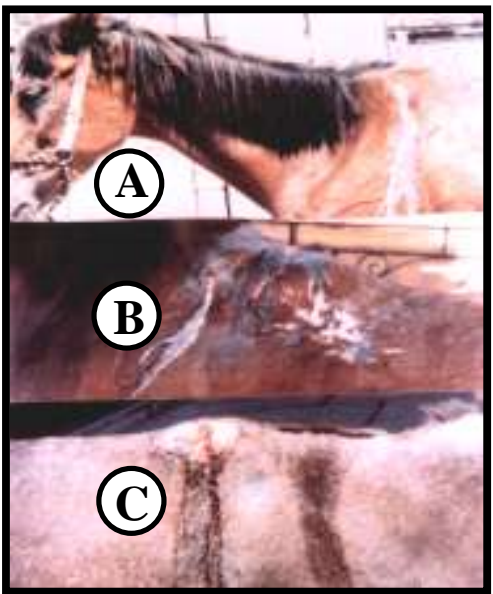

Fig. (5): Septic opened fistulous witherin mares $(A \& B)$ and in a don$\operatorname{key}(\mathrm{C})$ showing fistulae discharging purulent material to the outside.

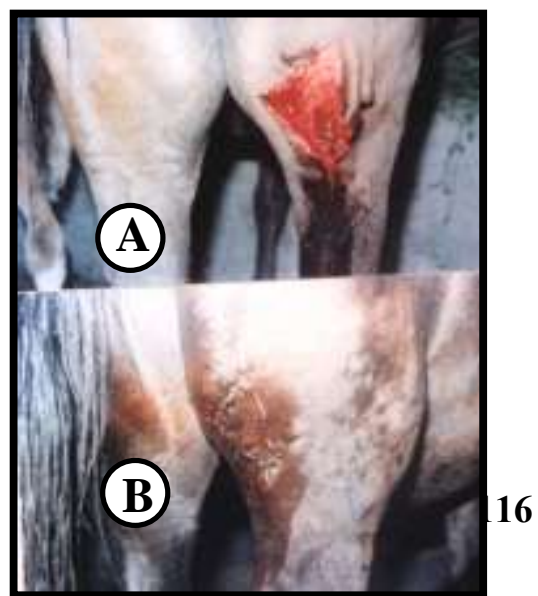

Fig. (7): Recent accidental lacerated wound involving the caudolateral aspect of the thigh (A) and 


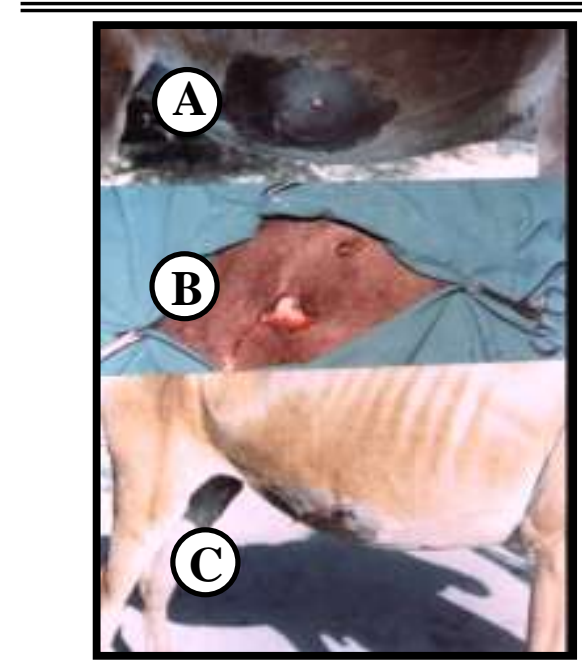

Fig.(8):Perforating abdominal wound at the caudal part of the ventrolateral aspect of the abdomen (A\& B).After its surgical treatment C.

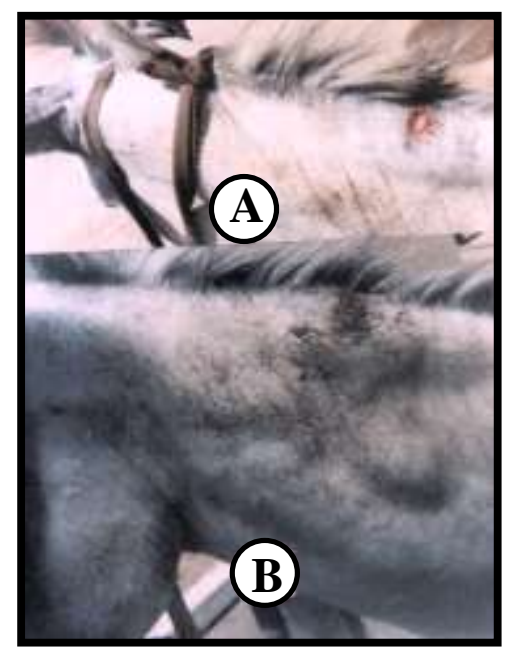

Fig. (10): Bite wounds located at the dorsum of the neck $(A \& B)$.

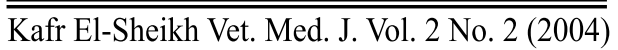

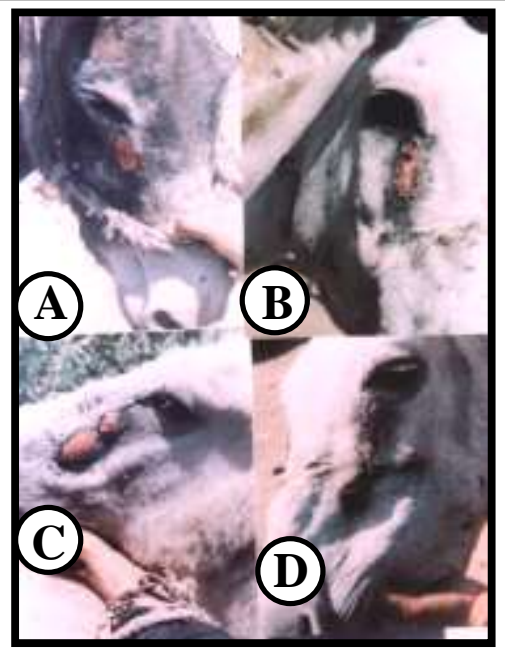

Fig.(9):Ulcerated fibrous granulomas a long the line of tear below the medial canthus of the eye (Ocular Habronemiasis) (A,B\&C) Habronema maska lesion after healing leaving a minimal scar (D).

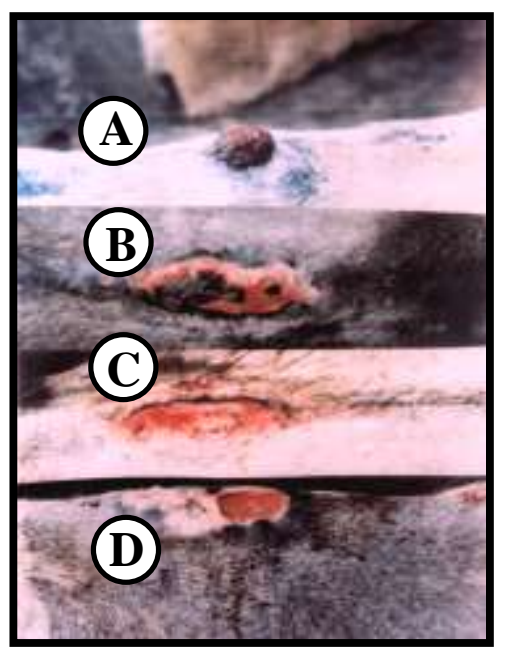

Fig. (11): Circular elevated sore back (A), covered with infected crust (B), after removal of the infected crust and dressing $(\mathrm{C})$ and partially healed sore back after its surgical excision (D). 


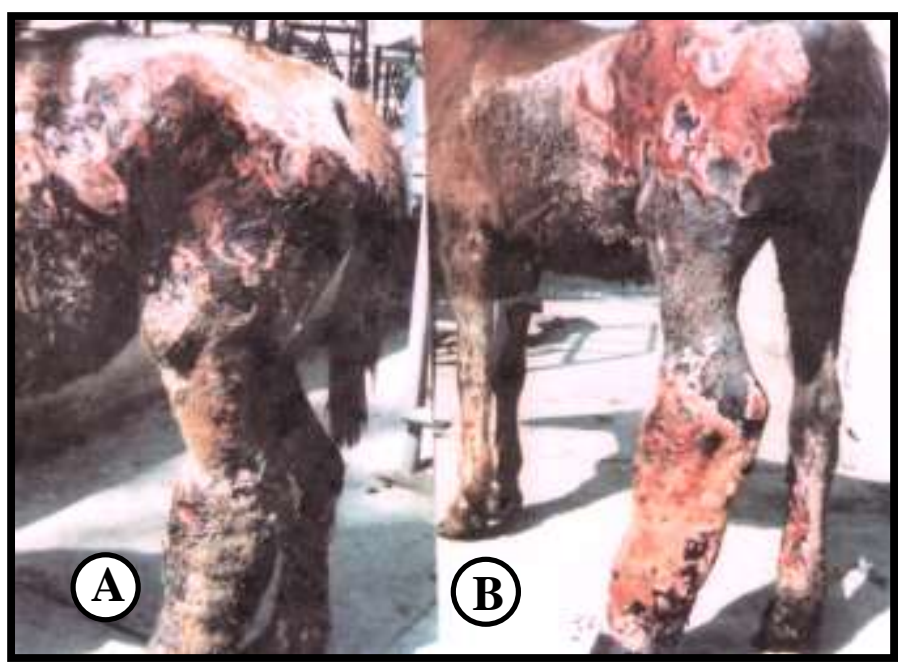

Fig. (12): Second and third degree thermal burn covering the lateral abdominal wall,flank gluteus, thigh and pes region(A)and after initial dressing (B).

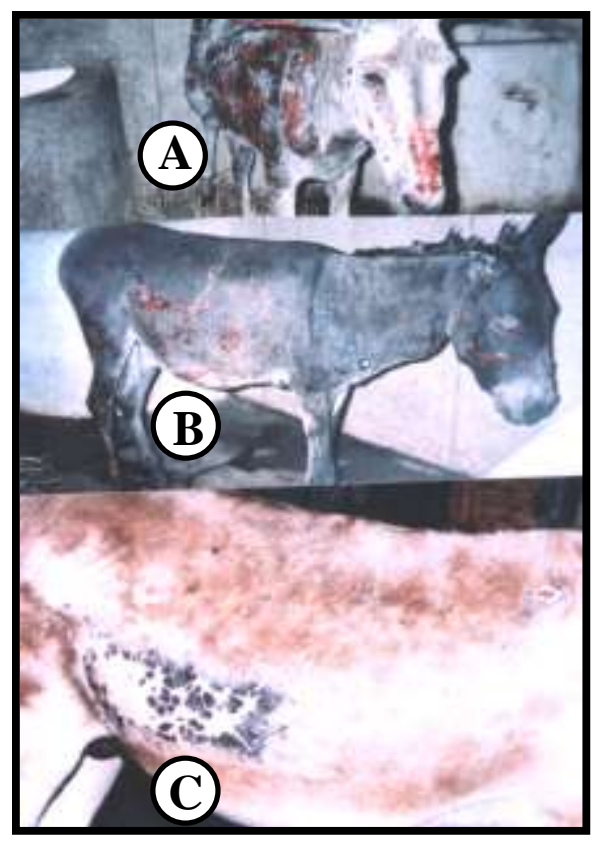

Fig. (13): First and second-degree thermal burns involving parts of the face,lateral thoracic and abdominal wall in donkeys (A\&B). Healed Seconddegree thermal burns leaving hairless scar on the ventro-lateral abdominal wall in a donkey $(\mathrm{C})$. 


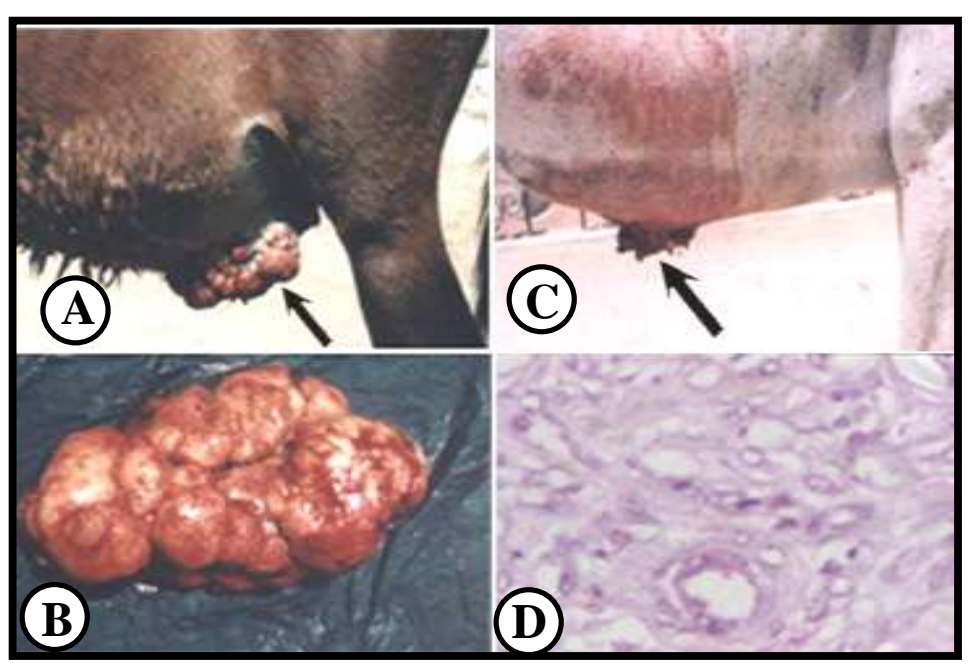

Fig. (14): (A): Fibroblastic type sarcoid in a foal. (B): The excised tumor mass. (C): Ulcerating fibroblastic mass at the ventral abdominal wall in a 4 years old mare.(D): The microscopic picture of fibroblastic type sarcoid which characterized by numerous fibroblasts with dilated blood vessels (H\&E X150).

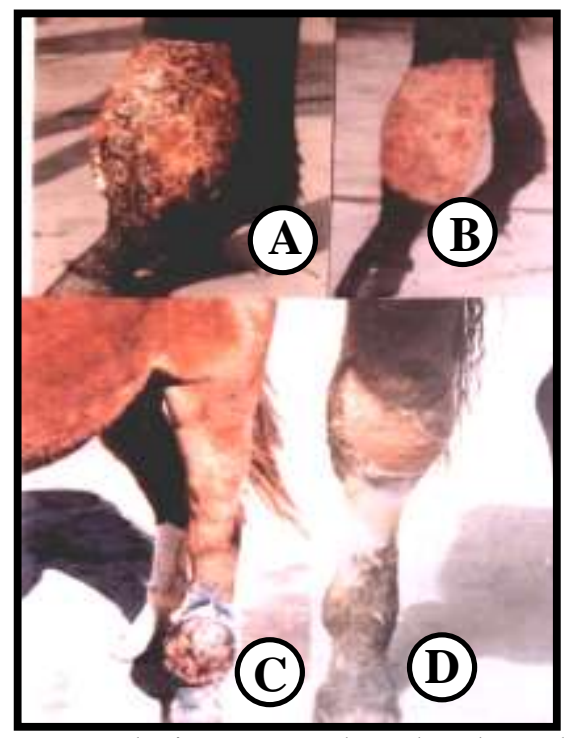

Fig. (15): Old exuberant granulating wound at the dorsolateral aspect of the pes (A) and after its surgical debridement.(B),Exuberant granulation tissues at the dorsal aspect just proximal to the fetlock joint. (C), and old granulating wound after dehiscence at the anterolateral aspect of the tarsal joint (D). 


\section{DISCUSSION}

The decision to close a wound or leave it open was difficult to be made and there were no strict criteria for making this decision. Therefore, the perfect clinical judgment was often the most reliable criterion for making such decision. The presence of inflammation in and around the wound is indicative of impending infection, and closure was contraindicated (Kawcak \& Baxter 1996 and Ealuppo et al., 1999).

In this study, the higher percentage of skin wounds were recorded in donkeys $59.2 \%$ in comparison to $38 \%$ in horses; this may be attributed to the misuse and abuse of donkeys as working animal and they usually subjected to undue stress as poor managemental style in addition to hard working as was also mentioned by Kandeel (1995).

The site of a wound is important for both prognosis and treatment. Wounds on the face and upper neck heal faster and more cosmetic than those on the trunk. Similar observations were reported by (Walton $\&$ Neal 1972). Upper limb wounds heal with less complications than those located distally. Wounds below the carpus and tarsus that heal by second intention with development of granulation tissues. This was in agreement with the results of Berton et al., (1985).

The higher incidence of skin injuries in head region (28.2\%) may be attributed to the unexpected large number of parasitic ulcerations distal to the medial canthus of the eyes. The resistance of a wound to infection is proportional to the density of the regional vasculature. Thus, contaminated wounds of the head can often be closed without untoward sequelae because of the generous blood supply (Hunt, 1981 and Sinha et al., 1991).

Traumatic wounds particularly laceration constituted the most common types in this study and were common in horses which often occur at predictable regions as chest, proximal region of pelvic limb and distal parts of the fore limbs. Similar findings were recorded by Kassem (1980) and Caron(1992). While saddle injures were mainly observed in donkeys 
due to anatomic variation of the back region and badly situated saddles as reported by Kandeel (1995).

The extremities were the most common locations for most of traumatic wound. This was also mentioned by Kassem (1980). The hind limbs especially the medial aspect of the stifle, hook and foot were most commonly affected than fore limb. Neck and thorax were common regions in case of bites in donkeys. (Kandeel, 1995 and Behery, 1997). The high occurrence of sharp object wounds mainly in lower limb was similar to that mentioned by Greenough \& Johnson (1988) and Lindsay (1988) and Kandeel et al.,(1992).

The exuberant granulation was more common in horses than in donkeys without specific age correlations. Berton et al. (1985) stated that, body weight is a factor in production of granulation tissues and wounds healing time.

Exuberant granulation tissue was a common complication of wounds of the lower limbs in the equine.It was most exuberant in pelvic limb than in fore limbs as mentioned by Berton et al., (1985); Shappell \& Little (1992) and Spurlock (1999). Immobilization is considered a factor in controlling exuberant granulation tissues production.

Silver (1982), Fretz et al., (1983) and Adams et al., (1999) mentioned that, wounds on the distal extremities of ponies produce little or no exuberant granulation when wounds exposed to air. While non-pressure bandage maintain slightly hypoxic tissues environment, wound moistness, and accumulation of surface exudates, which stimulate fibroplasia and neovascularization.

Surgical excision of granulation tissues and immobilization of the affected part gave good results.(Lindasy,1989). While in other study chronic exuberant granulation tissue was controlled by chemical cauterization of excess granulation tissue. These agents not only inhibit formation of granulation tissue but also they kill the migrating epithelial cells and increasing scaring. (Greenough \& Johnson, 1988). While cryogenic surgery 
effectively controls excess tissues formations but it may cause excessive scarring. (Fretz et al., 1983 and Behery 1992).

The back, the lateral thoracic wall, the cranial borders of the shoulder joints and the prominence of tuber coxae were the common seats for traumas. The same observations were obtained by Naviaux (1985) in horses and by Kandeel (1995) in donkeys. They attributed these wounds to hard working together with the continuous traumatization and friction induced by badly situated saddle and neck collars. In donkeys, the gluteal area is considered as the accelerator by hitting this area by blunt object or by sharp pointed ones. So it is a common seat for haematoma formation and punctured wounds. The recorded abdominal injuries were mainly due to falling and slipping during drafting, laying on sharp objects, trailering injury and blow from neibouring animals.

Sore back are old wounds at the back along the vertebral midline of donkeys. They may be caused by continuous irritation of unfit saddle. The lesions were circular ulcerated areas without tendency to heal accompanied with unhealthy hypergranulation with necrosis in its centre. Similar findings were reported by Kassem,(1980)and Frank,(1981). While Behery (1992) used cryosurgery with good results.

Burns recorded in the present study were $2^{\text {nd }}$ and $3^{\text {rd }}$ degrees including most of the body regions.Daily dressing with wound lavage using normal saline in addition to debridment if necessary as mentioned by Warden (1987) and Provost (1992).

Bite wounds of the skin are ranged from simple to extremely difficult injuries. The small puncture wounds of the skin are usually accompanied with torn of the underlying subcutaneous tissue . and muscular tissues. Similar findings were reported by Kandeel, (1995) and Behery (1997).

Concerning the reconstructive techniques applied in this work, it was evident that, they facilitated the closure of wound defects by a full thickness haired skin, centripetal closure as well as local skin flaps and undermining the surrounding tissues of wound defects. They were easily appli- 
cable techniques, least time consuming provided cosmetic appearance and reduced the healing time than other routine open wound management with no need for specific instruments. These findings are in agreement with that reported by Peyton(1981),Pavletic(1986\&1990)Bailey,(1992), and Behery, (1997).

Regardless the controversy concerning whether an open wound should be left without bandage.Improper bandage may be prone the wound to exuberant granulation tissues production (Fretz et al., 1983). While Berton (1989) and Stashak (1991) believed that, an excess tissue was related to body size and not bandaging. Semi-occlusive non-adherent pressure bandages protect the profile epithelial cells from desiccation, secondary contamination, self-mutilation and external trauma. Pressure bandaging is also useful for controlling exuberant fibroplasia(Lees et al., 1989; Spurlock \&Hani 1989; Haeard et al.,1993; Berry\& Sullins 2003 and Gomez et al., 2004).

It could be concluded that, the sites of the wound is important for both prognosis and treatment. The resistance of the wound to infection is proportional to the density of the regional vasculature; thus wounds of the head closed without untoward sequel because of the generous blood supply.

Open wounds of the trunk heal predominantly by contraction frequently with minimal blemish. Conversely open wounds of the limb heals with a less favorable final appearance owing to the resultant hairless scar or were often complicated by exuberant granulation tissue. Crushing wounds were more likely to become infected than clean sharp lacerations.

Life threatening emergencies such as uncontrolled hemorrhage, inadequate ventilation, circulatory decompensation and reaction to intense pain must be managed at first. Following stabilization, special attention should be directed at the wound and integrity of the surrounding tissues.

The reconstructive techniques applied in this work facilitated the closure of wound defects. Centripetal closure as well as local skin flaps and undermining the surrounding tissues of wound defects were easily applicable techniques with least time consuming and no need for specific instruments.

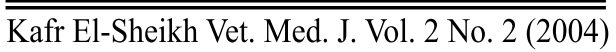




\section{REFERENCES}

- Adams A.P., Santschi E.M. and Mellen camp M.A. (1999): Antiba-cterial properties of a silver chloride-coated nylon wound dressing. Vet Surg. 28 (4): $219-225$.

- Bailey,J.V. (1992): Principles of reconstructive and plastic surgery .In Auer J.A. (ed.), Equine surgery. W.B. Saunders Co., Philadelphia, 244.

- Behery,A.E.(1992): Evaluation of cryosurgical applications in animals. M.V.SC. Dept. Of Surgery, Fac.Vet. Med. Zagazig University, Egypt.

- Behery, A.E. (1997): Skin surgery in animals. Ph. D. Thesis, Dept. Of Surgery, Fac. Vet. Med. Zagazig University, Egypt.

- Berry, D.B. and Sullins, K.E. (2003): Effect of topical application of antimicrobials and bandaging on healing and granulation tissue forma-tion in wounds of the distal aspect of the limbs in horses.Am J Vet Res. 64 (1) 88-92.

- Berton, A.L. (1989): Management of exuberant granulation tissue.Vet Clin. North Am. Large Anim pract 5:551

- Berton, A.L; Sullins, K.E.; Stashak, T.S. and Norrdin,R.W. (1985): Effect of Wound location and the use of topical collagen gel on exube-rant granulation tissue formation and wound healing in the horse and pony. Am. J. Vet. Res. 46:1438

- Caron, J. P. (1992): Management of superficial wounds. In Equine Surgery by Auer, J. A., Chap. 24, W.B. Saunders Co. Philadelphia.

- Ealuppo, L.D.; Pascoe, J.R.;Jang,S.S.; Willits, N.A. and Greenman, S.L. (1999): Evaluation of Iodophor skin preparation techniques and factors influencing drainage from ventral midline incisions in horses. JAVMA 215 (7): 963-969.

- Frank, E.R. (1981): Veterinary Surgery: Seventh Ed. Chapter VIII. C.B.S Publ. \& Distrib, Shadra, Delhi, India. P. 231

Kafr El-Sheikh Vet. Med. J. Vol. 2 No. 2 (2004) 
- French D.A. (1994): Soft tissue emergency in adult horses. Vet. Clin North Am Equine Pract .10(3):575-590.

- Fretz,P.B.; Martin,G.S.and Jacobs, k.A. (1983): Treatment of exub-erant granulation tissue in the horse: Evaluation of four methods. Vet Surgery; 12: 137-140.

- Gomez, J.H.; Schumacher, J.;Lauten S.D.;Sartin E.A.;Hath Cock; T.L. and Swaim,S.F.(2004): Effect of 3 biologic dressings on healing of cutaneous wounds on the limbs of horses.Can J Vet Res.68(1):49-55.

- Greenough, P.R. and Johnson, L.(1988): The integumentary system skin, hoof, claw, and appendages. In Oehme .F.W. (ed): Textbook of large Animal surgery. Baltimane, Williams \& Wilkins, p 154.

- Haeard, R.D; Stashak, T.S. and Baxter, G.M. (1993): Evaluation of occlusive dressings for management of full thickness excisional wounds on the distal portion of the limbs of horses Am J Vet Res.54 (12):2150 -2154.

- Hunt, T.R. (1981): Surgical wound infection. An overview.Am J Med 70: 712.

- Kandeel, A. E. (1995): Study on the common locations of wounds in donkeys, Zag. Vet. J. 23, (4): 25-37.

- Kandeel, A.E.; Abd El-Aal, A.M. and El-Shair, M.A. (1992): Surg-ical management of sever limb injuries in equine(clinical report of two cases), Zag. Vet. J., 20, 677.

- Kassem,M.M.(1980):Studies on surgical affections of the skin in dom-estic animals in Egypt M.V. Sc. Surg. Obst. Gynaec. \& A.I. Dept.,Fac. Vet. Med., Alex Univ.

- Kawcak,C.E.and Baxter,G.M. (1996): Surgical materials and wound closure techniques . Vet. Clin North Am Equine Pract .12(2): 195-205. 
- Lees,M.J;Fretz,P.B.;Bailey, J. V. and Jacobs, K. A. (1989): Second - intention wound healing. Compend. contin. Educ. Pract. Vet. 11:857.

- Lindsay, W. A. (1988): Wound healing in horses guidelines for class-ification. Vet. Med., Equine Pract. P. 387 - 401.

- Lindsay, W. A. (1989): Equine bandaging techniques Vet. Clin. North Am. Equine Pract. 5:513.

- Naviaux, J. L. (1985): Horses in health and diseases. $2^{\text {nd }}$ Ed., Chap. 13 Lea \& Febiger, Philadelphia, U.S.A.

- Pavletic, M.M. (1986): Undermining for repair of large skin defect in small animals. Mod. Vet. Pract 76, 13.

- Pavletic, M.M. (1990): Skin flaps in reconstructive surgery Vet. Clin North Am. 20-81.

- Peyton, L.G. (1981): Reconstructive surgical technique in the horse. JAVMA. 179, 46.

- Provost, P.J. (1992): Thermal injuries. In Auer J.A. Equine surgery. W.B. Saunders Co., Philadelphia, 285.

- Romatowski, J.(1989): Prevention and control of surgical wound inf-ection. JAVMA. Vol. 194, 107-113

- Shappell, K.K. and Little, C.B. (1992): Special surgical procedures for equine skin. In Auer J.A. Equine surgery W.B. Saunders Co., Phil-adelphia. P 272.

- Silver, I. A. (1982): Basic physiology of wound healing in the horse. Equine Vet. J.; 14: 7-15.

- Sinha, A.K., Henderickson D.A. and Kannegiter A.M. (1991): Head trauma in two horses. Vet .Rec . 128(22): 518-521.

- Spurlock,G.H(1999): Management of traumatic tendon laceration.Vet. Clin North Am Equine Pract. 5 (3): 575-590. 
- Spurlock, S.L. and Hani E.A. (1989): Antibiotics in the treatment of wounds. Vet. Clin North Am Equine Pract. 5 (3): 465-482.

- Stashak, T.S. (1991): Equine wound management. Lea and Febiger, Philadelphia 1-18, 19-34.

- Walton, G.S. and Neal, P.A. (1972): Observations on wound healing in the horse: The role of wound contraction. Equine Vet. J. 4: 93- 97.

- Warden, G.D. (1987): Outpatient care of thermal injuries. Surg. Clin. North. Am. 67:147.

التقييم السريري والتعامل مع الجروح في الفصيلة الخيلية

جمال احمد الصياد" وعادل التابعي زغلول و جمال عبد القتاح قروف

* قسم الجراحة كلية الطب البيطري بكفر الثيخ جامعة طنطا.

قسم الجراحة وإلتخدير والأثعة كلية الطب البيطري جامعة المنصورة.

أجريت هذه الدراسة الحقلية على عدد 355 حيوان جر من الفصيلة الخيلية وقد كانت

(135 حصان) بنسبة 38\% وعدد (210 حمار) بنسبة 59.2\% وعدد (10 بغل) بنسبة 2.8\% حيث أنهم يعانون جميعا من أنواع مختلفة من الجروح وقد سجلت هذه الدراسة نسب الجروح المختلفة على حسب توزيعها في مناطق الجسم المختلفة للحيوانات وكانت كالتالي:

منطقة الرأس بنسبة 28.2\%، منطقة الرقبة 5.6\%، ومنطقة الكتف 5.6\%، منطقة الظهر 2.8\%، منطقة الاليا 2.8\% منطقة الصدر 5.6\%، منطقة البطن 5.6\%،أما القوائم الأمامية كانت نسبة الجروح بها 19.7\% وسجلت القوائم الخلفية نسبة 25.4\% من نسبة الجروح الكلية.

كما اهتمت الدراسة بتحديد المسبيات لهذه الجروح و قد سجلت الإصابات بالأجسام الحادة المدببة أعلى نسبة إصابات 16 \% بينما الإصابات الناتجة عن النطح كانت اقل نسبة 
اصابات80.8\%كما سجلت الدراسة نسبة عالية من الإصابات بالجروح أسفل مفصلي الركبة والعرقوب

$$
\text { بنسبة 19.7\% و 25.4\% على التوالي. }
$$

وقد نم التعامل مع الأنواع المختلفة للجروح على الأساس العلمي المنبع في علاج الجروح. حيث تم التعامل مع الجروح الحديثة الغير ملوثة لتلتئم بالقصد الأول وقد نم التعامل مع الجروح الملوثة

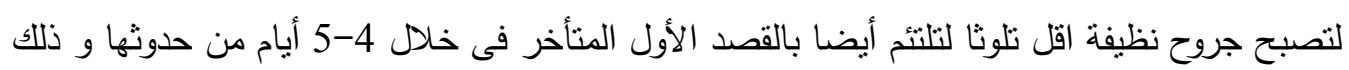
قبل تكوين الأنسجة الليفية في تلك الجروح0 هذا وقد نم مناقثة هذه النتائج مع مثيلاتها من النتائج الأخرى فى الأبحاث السابقة. 